\title{
AN EXPERIMENT FOR DETERMINING THE DEPTH OF PENETRATION OF VARIOUS PHOSPHATES WITH THE AID OF $\mathrm{P}^{32}{ }^{1}$ )
}

\author{
K. H. S. HAASJES and H. A. SISSINGH
}

\section{SUMMARY}

An attempt has been made to use P32 in obtaining confirmation on the well-known fact that the phosphatic fertilizer penetrates the soil more quickly when the phosphoric acid dissolves more readily. Two methods have been employed. Measurements of radio-activity have been taken at the profile as such and at the isolated soil layers. These results have been compared with the P-values and the $\mathrm{PO}_{4}$-content (Morgan). The soil used for this experiment had a high fixation capacity. The results obtained compared favourably with the $\mathrm{PO}_{4}$-content in the Morgan extract.

It was evident that superphosphate penetrated more rapidly into the soil than di-calciumphate. As regards tri-calciumphosphate practically no movement whatsoever occurred during the 27 days of the experiments in spite of liberal wetting during the first 11 days.

Experiments were also made with plants in Mitscherlich pots and these confirmed the fact, that water soluble phosphoric acid is quickly assimilated. In these experiments the difference in action of phosphates with different solublity was not the only object of observation but also the distribution through the plant of the assimilated $\mathrm{P}_{2} \mathrm{O}_{5}$.

Finally the physiological differences were pointed out between individual plants of one crop and between homologous parts of one individual plant.

\section{AIM OF THE EXPERIMENT}

Careful sampling of the successive soil layers is required if the penetration of phosphates, when applied on the surface, is to be determined chemically. Added to this will be much laborious and careful analytical work.

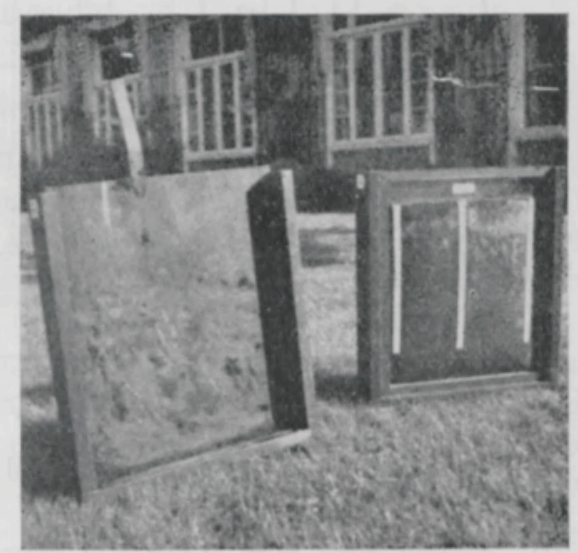

Рното 1. Wooden thoughs.

Right : the slide of hard board has been removed and the body of soil is visible through the plastic window.

Left : the body of soil has been cut vertically by the iron plate which is fitted in the slits. Half of the body of soil has been removed already.

1) Received for publication January $12,1953$. 


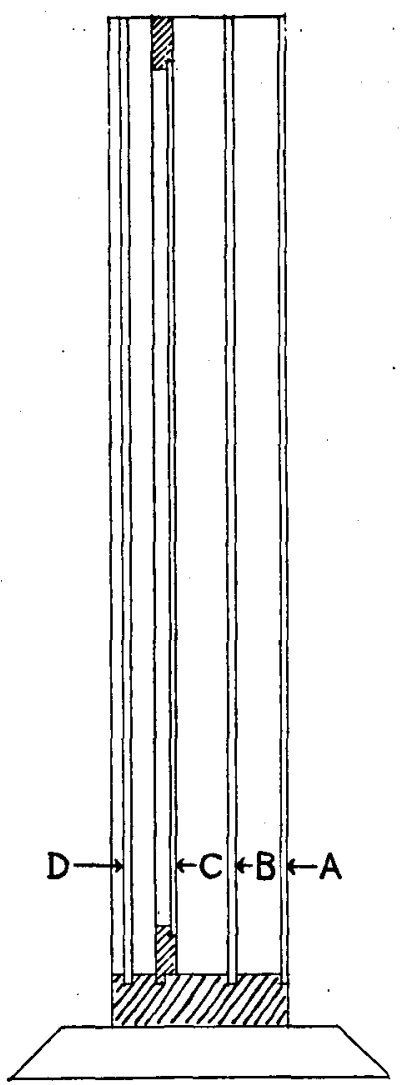

1.

Vertical cut

A Back

B Iron plate

C Plastic panel

D Slide of hard board

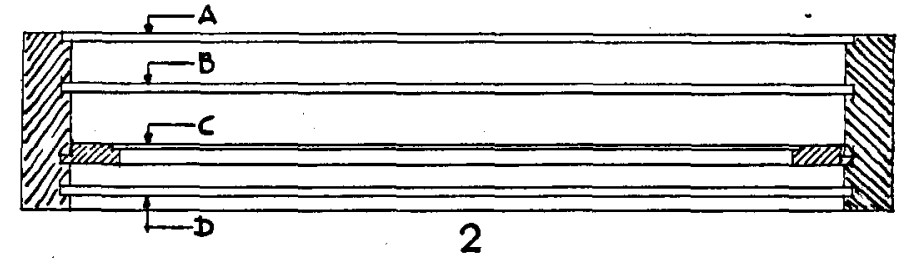

Horizontal cut

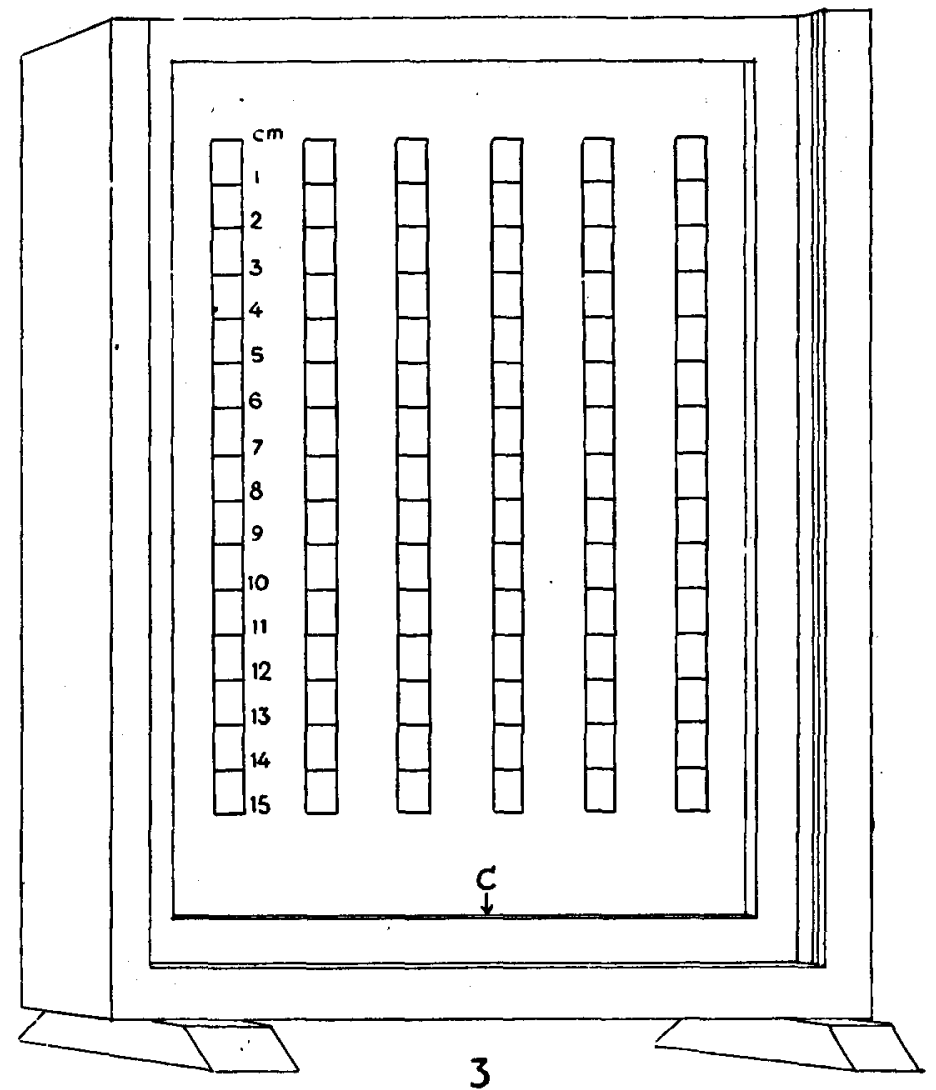

Lateral view

Fig. 1. Soll trough With IRON plate for cutting soll.

In an attempt to find an equally accurate but simpler method for the determination of the phosphate distribution in the soil, it was determined to which extent the results of measurements of radio-activity in various soil layers are comparable to the figures of chemical soil analysis. Should the agreement be satisfactory, then it would be possible with the aid of P32 to collect data on the various depths of penetration of phosphates with a different solubility. 


\section{a The soil}

A well mixed soil was chosen, taken from the top $8^{\prime \prime}$ of sandy arable land in "De Bilt". The chemical analysis of this soil shows :

\begin{tabular}{|c|c|c|c|c|c|c|}
\hline $\mathrm{pH}-\mathrm{H}_{2} \mathrm{O}$ & \multicolumn{2}{|c|}{5.00} & & $\mathrm{PO}_{4}$ & \multicolumn{2}{|c|}{4.5 p.p.m. } \\
\hline pH-KCl & 4. & & & $\mathrm{NO}_{3}$ & 15 & p.p.m. \\
\hline $\mathrm{K}$ & 42 & p.p.m. & & $\mathrm{NH}_{4}$ & 15 & p.p.n \\
\hline $\mathrm{Mg}$ & 3 & p.p.m. & & $\mathrm{SO}_{4}$ & 400 & p.p.m. \\
\hline $\mathrm{Ca}$ & 300 & p.p.m. & & $\mathrm{Cl}$ & 10 & p.p.m. \\
\hline $\mathrm{Mn}$ & 15 & p.p.m. & & P-citr. & 39 & \\
\hline $\mathrm{Fe}$ & 30 & p.p.m. & & org. matter & .5 .6 & \\
\hline
\end{tabular}

Apparently, the $\mathrm{PO}_{4}$-content of the soil is low and the Fe-content very high. The Ca-content appears to be moderately high and the $\mathrm{pH}$ fairly low.

\section{$b$ The troughs}

Wooden troughs of 4.5 (width) $\times 31 \frac{1}{2}$ (length) $\times 39 \%$ cm (height) were employed. One side of $31 \frac{1}{2} \times 39 \frac{1}{2} \mathrm{~cm}$ consisted of a window of transparent synthetic resin $0.8 \mathrm{~mm}$ thick, which only absorbs a very small percentage of radio-active radiation as had been shown by previous experiments. A slide of hard board in front of the synthetic resin prevented daylight penetrating into the deeper layers. The surface of the soil amounted to some $140 \mathrm{~cm}^{3}$, the volume nearly $5000 \mathrm{~cm}^{3}$.

In the $4 \frac{1}{2} \mathrm{~cm}$ wide walls and bottom a slit was made at $2 \frac{1}{2} \mathrm{~cm}$ from the back, in which fitted a sheet of iron enabling the body of soil to be cut for taking measurements in the centre of the soil mass. Fig. 1 shows the construction of one of these troughs.

\section{c Experimental treatments}

The troughs were filled with soil up to $5 \mathrm{~cm}$ from the top. $\mathrm{P}_{2} \mathrm{O}_{5}$ was added in amounts of $300 \mathrm{mg}$ per trough, corresponding with approximately $210 \mathrm{~kg}$ of $\mathrm{P}_{2} \mathrm{O}_{5}$ per ha. The fertilizers used were superphosphate, di-calciumphosphate and tri-calciumphosphate. These were applied as solids and worked lightly into the top half $\mathrm{cm}$ of the soil.

Owing to the difficulties encountered with the preparation of ammoniumphosphates as solids at the Institute for Nuclear Physical Research in Amsterdam a second series of tests was set up using mono- and di-ammoniumphosphate in solution, of which also $300 \mathrm{mg} \mathrm{P}_{2} \mathrm{O}_{5}$ were added to each trough. Altogether, therefore, there were five objects i.e. a dosage of $300 \mathrm{mg} \mathrm{P}_{2} \mathrm{O}_{5}$ in five forms. The experiment was carried out in duplicate.

The series with ammoniumphosphate (fertilizer in solution) may not be compared with the other troughs (fertilizer in powder form) as regards depth of penetration, but this is of no consequence for the comparison between the measurements of radio-activity and the chemical analysis.

The fertilizers were applied on the 19th April 1952. From the 19th to 30th of April $10 \mathrm{~mm}$ of water were given daily, the evaporation being considerable due to a warm location. The soil was bare. 


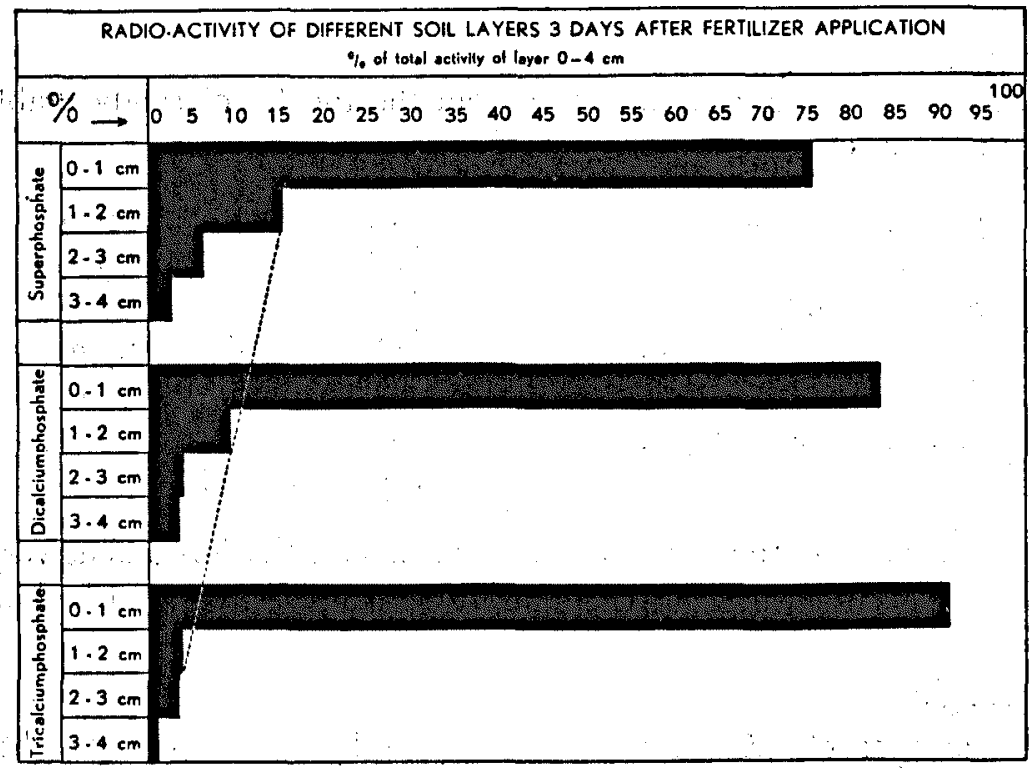

Fig. 2. Results OF MEASUREMENTS OF RADIO-ACTIVITY THROUGH THE WINDOW OF SYNTHETIC RESIN AT THE SIDE OF THE BODY OF SOIL; 3 DAYS AFTER FERTILIZER APPLICATION.

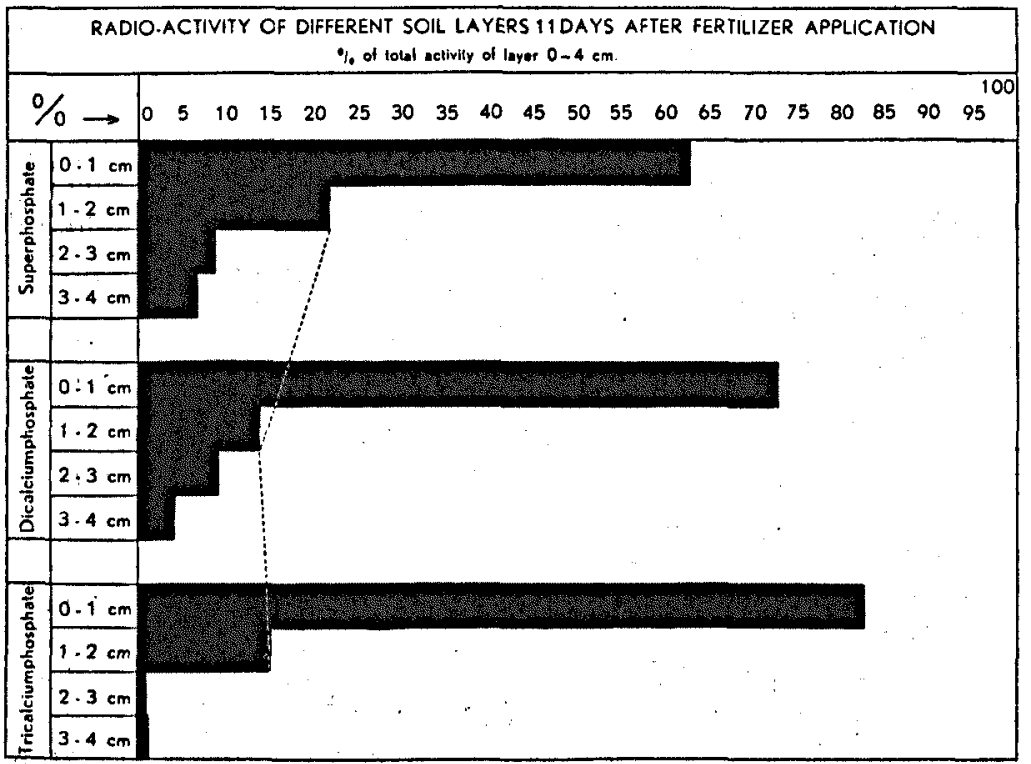

Fig. 3. Results of Phofile measurements, the body of Soll having been CUT 11 days AFTER FERTILIZER APPLICATION. 


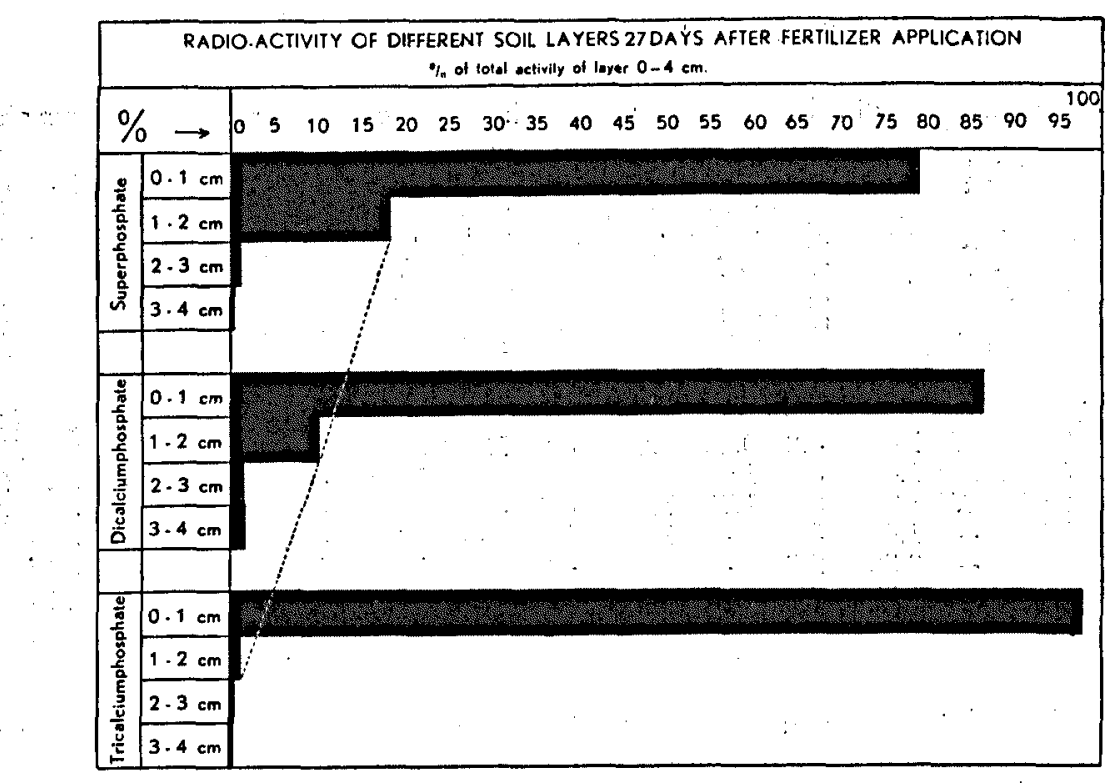

Fig. 4. Results of Radio-ACtivity MEASUREMENTS OF SOLL LAYERS CUT FROM the PRofile; 27 DAYS AFTER FERTIL.IZER APPLICATION.

\section{d The measurements}

The activity of each dose of fertilizer of $300 \mathrm{mg} \mathrm{P}_{2} \mathrm{O}_{5}$ amounted to $300 \mu \mathrm{c}$ on. April 18th.

It appeared that measurements through the window of synthetic resin were not reliable because in some cases there was insufficient contact between this window and the soil, due to some bulging of the synthetic resin. Therefore the bodies of soil were cut with the iron plate mentioned sub. $b$, avoiding as much as possible the pressing down of particles of fertilizer lying on the surface of the soil. The profile thus obtained was covered with a sheet of synthetic resin marked off in $\mathrm{cm}^{3}$.

Measurements were carried out on this profile in six vertical bands, $5 \mathrm{~cm}$ apart, as shown by fig. 1. Each band was tested, ' centimetre by centimetre, with the counter tube of the Geigercounter. Thus six values per soil layer of one $\mathrm{cm}$ were obtained. The figures shown are the averages of these six observations per centimetre of depth. They were taken on the April 30th or 11 days after the application of the fertilizer. The duplicate troughs were cut on May 16th i.e. after 27 days; the soil layers $0-1 \mathrm{~cm}, 1-2 \mathrm{~cm}, 2-3 \mathrm{~cm}$ etc. were cut from the profile. In a petri-dish $30 \mathrm{~g}$ of soil of each layer were mixed with $14 \mathrm{cc}$ of water into a paste, the radio-activity of which was determined also. The same samples were used for the determination of $\mathrm{pH}, \mathrm{P}$-value and p.p.m. $\mathrm{PO}_{4}$ in the Morgan extract.

\section{COMPARISON OF THE MEASUREMENTS OF RADIO-ACTIVITY AND CHEMICAL ANALYSIS}

The activity values show the number of counts per minute less the average per minute of a sufficient number of blank measurements. The activity value is a measure of the quantity of phosphate in a certain soil layer originating from the fertilizer applied to the surface. 
Table 1. Results of soil analysis.

\begin{tabular}{|c|c|c|c|c|c|c|c|c|c|c|c|c|c|c|c|}
\hline \multirow[b]{2}{*}{$\frac{\mathbf{c m}}{\stackrel{0}{0}}$} & \multicolumn{3}{|c|}{ superphosph. } & \multicolumn{3}{|c|}{ di-calc.ph. } & \multicolumn{3}{|c|}{ tri-calc.ph. } & \multicolumn{3}{|c|}{ mono-amm.ph. } & \multicolumn{3}{|c|}{ di-amm.ph. } \\
\hline & 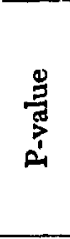 & 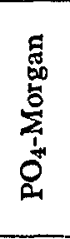 & 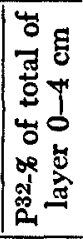 & 莍 & 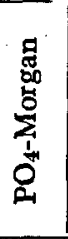 & 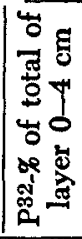 & 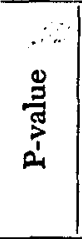 & 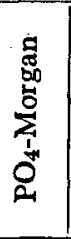 & 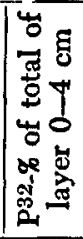 & 苞 & 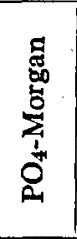 & 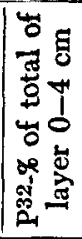 & م. & 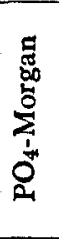 & 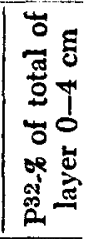 \\
\hline $\begin{array}{l}0-1 \\
1-2 \\
2-3 \\
3-4 \\
4-5 \\
5-6\end{array}$ & $\begin{array}{l}7.00 \\
2.00 \\
0.95 \\
0.65 \\
0.75 \\
1.00 \\
1.10\end{array}$ & $\begin{array}{r}19.6 \\
7.3 \\
3.3 \\
3.6 \\
3.5 \\
3.3 \\
.5 .4\end{array}$ & $\begin{array}{r}78.98 \\
18.47 \\
2.08 \\
0.47 \\
= \\
=\end{array}$ & $\begin{array}{l}3.40 \\
1.40 \\
1.40 \\
1.30 \\
1.05 \\
0.80 \\
1.00\end{array}$ & $\begin{array}{l}8.8 \\
4.3 \\
3.1 \\
3.4 \\
3.3 \\
2.8 \\
2.9\end{array}$ & $\begin{array}{c}86.51 \\
10.15 \\
1.64 \\
1.70 \\
= \\
=\end{array}$ & $\begin{array}{c}2.00 \\
1.00 \\
0.95 \\
1.30 \\
1.15 \\
0.95 \\
-\end{array}$ & $\begin{array}{c}8.3 \\
3.3 \\
3.8 \\
3.9 \\
3.8 \\
4.3 \\
-\end{array}$ & $\mid \begin{array}{c}97.81 \\
1.4 \\
0.54 \\
0.25 \\
- \\
-\end{array}$ & & $\begin{array}{r}11.8 \\
7.0 \\
3.3 \\
3.1 \\
3.3 \\
3.2 \\
3.7\end{array}$ & $\begin{array}{r}73.00 \\
23.50 \\
2.80 \\
0.70 \\
- \\
-\end{array}$ & & $\begin{array}{l}9.3 \\
7.6 \\
5.1 \\
4.5 \\
4.4\end{array}$ & $\begin{array}{r}74.70 \\
22.23 \\
2.72 \\
0.35 \\
- \\
- \\
-\end{array}$ \\
\hline
\end{tabular}

The results of the measurements on the 22nd and the 30th April at the profile and of the 16th May in the petri-dishes are shown in figures 2, 3 and 4.

The choice $0-4 \mathrm{~cm}$ is arbitrary. In the majority of cases there was very little activity in layers below a depth of $4 \mathrm{~cm}$. Below $6 \mathrm{~cm} \mathrm{P}$ P $^{2}$ was not evident in any single case.

We notice that with direct measurements at the synthetic resin panel and sheet as well as with indirect measurements via the petri-dishes the theoretical expectations are fulfilled. When the phosphatic fertilizer is less soluble, a greater accumulation in the top layer has occured and the penetration to the lower layers was less. The direct measuring method is less laborious. As regards accuracy we have the advantage that measurements may be made directly at the undisturbed profile, but the disadvantage that radiations from the layer overlying the layer to be measured, may reach the Geigercounter tube. This may, therefore, give a somewhat exaggerated figure for the depth of penetration. For this reason we prefer the petri-dish method.

According to figure $3,93.26 \%$ of the superphosphate, $95.87 \%$ of the di-calciumphosphate and $98.70 \%$ of the tri-calciumphosphate are found in the $0-3 \mathrm{~cm}$ layer. According to figure 4, these values for the 0-2 cm layer are: $97.45 \%$ and $96.66 \%$ for superphosphate and di-calciumphosphate respectively. In this case $99.21 \%$ of the tri-calciumphosphate is found in the $0-2 \mathrm{~cm}$ layer.

To enable an establishment of a relationship between the depth of penetration and the value of the phosphoric acid for plant growth, the chemical analyses have disregarded the P-total value and only considered the P-value (waterextraction) and the $\mathrm{PO}_{4}$-value (p.p.m. in the Morgan extract).

For easy comparison to the measurements of radio-activity in the petridishes, the values of the latter have been included in table 1 .

A linear relationship must be expected between the results of the radioactivity measurements and the penetration of the phosphate, but this is not true for the chemical analysis method, because fixation of phosphate may occur to a greater or lesser degree and it may be assumed that the penetration of phosphate may be traced, at best, to an equal depth but more probably to a lesser depth. Also the P-values will be more influenced by the fixation than the $\mathrm{PO}_{4}$-values, found in the acid Morgan extract. 


\section{P-value}

In the top layer $(0-1 \mathrm{~cm})$ the $P$-value of the samples having received water soluble phosphate is considerably higher than that for less water-soluble or water-insoluble phosphates. It is possible that in this layer incompletely dissolved fertilizer particles have contributed to the high phosphatic values. This effect can not be expected in the 1-2 cm layer anymore because the fertilizers had been worked into the soil to a depth of $1 \frac{1}{2} \mathrm{~cm}$ only. In this layer monoand di-ammoniumphosphate as well as superphosphate still show a considerable increase of the P-value compared with that of the lower layers. The virtually water-insoluble di- and tri-calciumphosphate show practically no increase of the P-value here.

In this 1-2 cm layer the P-values, and still more so the increases of the $\mathrm{P}$-values, indicate a clear relationship with the corresponding percentages of activity. With the exception of di-ammoniumphosphate all fertilizers show virtually identical P-values in the 2-3 cm layer.

With some fertilizers the remarkable tendency of passing a minimum is noted in the course of the phosphate values to the lower layers. This symptom needs further examination.

\section{$\mathrm{PO}_{4}$-Morgan}

The course of the values found with this method is roughly equal to that of the P-values. Here, too, the penetration of the phosphate can generally not be traced beyond the 1-2 cm layer, although the results of the activity measurements for the 2-3 and 3-4 cm layer still show differences between the fertilizers.

The values for the $1-2 \mathrm{~cm}$ layer again show a clear relationship with the activity percentages; moreover, a pronounced difference between water-soluble and insoluble phosphatic fertilizers is brought to light. The $\mathrm{PO}_{4}$-figures for mono-ammoniumphosphate, di-ammoniumphosphate and superphosphate are 7.0, 7.6 and 7.3 respectivily, whereas those for di- and tri-calciumphosphate amount to 4.3 and 3.3 respectivily. The increases of the $\mathrm{PO}_{4}$-values as compared to those of the lower layers are respectivily $3.7,3.8,3.7,1.3$ and nearly 0 .

Thus, the importance of the water solubility for the distribution in the soil is again clearly demonstrated.

\section{Fixation capacity of the soil}

The following experiment gave an illustration of the fixation capacity of the soil.

$100 \mathrm{~g}$ of air-dried soil from the lower layers of the soil-troughs were mixed (dry) in a petri-dish with increasing quantities of $18 \%$ powdered superphosphate. A previously determined volume of water was then added until the point of collapse and subsequently the soil paste was thoroughly mixed with a spatula. Finally the soil was dried at room temperature during 6 days. The $\mathrm{P}$-value and $\mathrm{PO}_{4}$-Morgan were then determined.

The fixation capacity of this soil is evidently very high. As a consequence the added phosphates could not penetrate deeply into the soil of this trough experiment.

In the second part of table 2 a fixation of over $100 \%$ is observed when low dosages $\left(2-4 \mathrm{mg} \mathrm{P}_{2} \mathrm{O}_{5}\right.$ ) are applied. Similar results were obtained with phosphates other than superphosphate, e.g. mono-potassiumphosphate. Further 
Table 2. Results of the P-fixation experiments.

\begin{tabular}{|c|c|c|c|c|c|}
\hline $\begin{array}{c}\text { Phosphate } \\
\text { added as } \\
18 \% \text { superph. } \\
\text { per } 100 \mathrm{~g} \\
\text { of soil }\end{array}$ & $\begin{array}{l}\text { Measured } \\
\text { concentra- } \\
\text { tion of the } \\
\text { extract }\end{array}$ & $\begin{array}{l}\text { Increase of } \\
\text { concentra- } \\
\text { tion }\end{array}$ & $\begin{array}{l}\text { Expected } \\
\text { increase of } \\
\text { concentra- } \\
\text { tion }\end{array}$ & $\begin{array}{l}\text { Increase of } \\
\text { concentra- } \\
\text { tion lower } \\
\text { than } \\
\text { expected }\end{array}$ & Fixation $\%$ \\
\hline 1 & 2 & 3 & 4 & 5 & 6 \\
\hline mgr. $\mathrm{PO}_{4}$ & $\underset{\text { Morgan }}{\text { p.p.m. } \mathrm{PO}_{4}}$ & $\underset{\text { Morgan }}{\text { p.p.m. }} \mathrm{PO}_{4}$ & $\begin{array}{l}\text { p.p.m.. } \mathrm{PO}_{4} \\
\text { Morgan }\end{array}$ & $\underset{\substack{\text { porgan } \\
4-3}}{\text { p.m. } \mathrm{PO}_{4}}$ & $\frac{5}{4} \times 100 \%$ \\
\hline $\begin{array}{c}0 \\
2.65 \\
5.35 \\
16.05 \\
32.10\end{array}$ & $\begin{array}{l}4.5 \\
4.7 \\
5.1 \\
6.3 \\
8.9\end{array}$ & $\begin{array}{l}\overline{0.2} \\
0.6 \\
1.8 \\
4.4\end{array}$ & $\begin{array}{r}\overline{11.4} \\
22.8 \\
68.4 \\
136.8\end{array}$ & $\begin{array}{r}\overline{11} .2 \\
22.2 \\
66.6 \\
132.4\end{array}$ & $\begin{array}{l}\overrightarrow{98.3} \\
97.4 \\
97.4 \\
96.8\end{array}$ \\
\hline mgr. $\mathrm{P}_{2} \mathrm{O}_{5}$ & $\underset{\text { (P-value) }}{\text { p.p.m. }} \mathrm{P}_{2} \mathrm{O}_{\text {s }}$ & p.p.m. $\mathrm{P}_{2} \mathrm{O}_{5}$ & p.p.m. $\mathrm{P}_{2} \mathrm{O}_{5}$ & p.p.m. ${ }_{4-3} \mathrm{P}_{2} \mathrm{O}_{6}$ & $\frac{5}{4} \times 100 x$ \\
\hline $\begin{array}{r}0 \\
2 \\
4 \\
12 \\
24\end{array}$ & $\begin{array}{l}2.85 \\
2.75 \\
2.75 \\
2.85 \\
3.40\end{array}$ & $\begin{array}{l}-\overline{0.1} \\
-0.1 \\
0 \\
0.55\end{array}$ & $\begin{array}{r}\overline{2} \\
4 \\
12 \\
24\end{array}$ & $\begin{array}{c}\overline{2} .1 \\
4.1 \\
12.0 \\
23.45\end{array}$ & $\begin{array}{c}105 \\
105 \\
100 \\
97.7\end{array}$ \\
\hline
\end{tabular}

research is in progress regarding the problem whether phosphate-fixing soil components become active as a result of fertilizer application.

\section{SOME CONCLUSIONS IN CONNECTION WITH THE DEPTH OF PENETRATION}

Since the values of the chemical analysis evidently show the greatest resemblance with the measurements of radio-activity after the petri-dish method, we shall study these figures in more detail.

The two ammoniumphosphates which have been applied to the soil as liquids differ very little. During the 27 days' duration of the experiment a noticeable quantity of the phosphate has penetrated into the $2-3 \mathrm{~cm}$ layer.

It is remarkable that in all five cases chemical analysis has not traced the phosphates to the same extent as has been accomplished with measurements of radio-activity. This must be attributed to the fixation capacity of the soil as has been proved by means of the experiment described in the previous paragraph.

Phosphate therefore, does penetrate into the deeper layers of the soil but to which extent this phosphate is of direct significance for plant nutrition still remains to be verified. The fact that $\mathrm{P}^{32}$ can trace the downward movement of phosphate farther than the determination of the $\mathrm{P}$-value or of the $\mathrm{PO}_{4}$ content is of some importance. It proves that migration of phosphate occurs. A locally decreased fixation capacity will no doubt be the result. We may assume that during its passage through the soil part of this phosphate can be absorbed by plant roots before the remainder is fixed in either reversible or irreversible form.

The differences in depth of penetration of superphosphate, di-calciumphosphate and tri-calciumphosphate are in accordance with the theoretical expecta- 


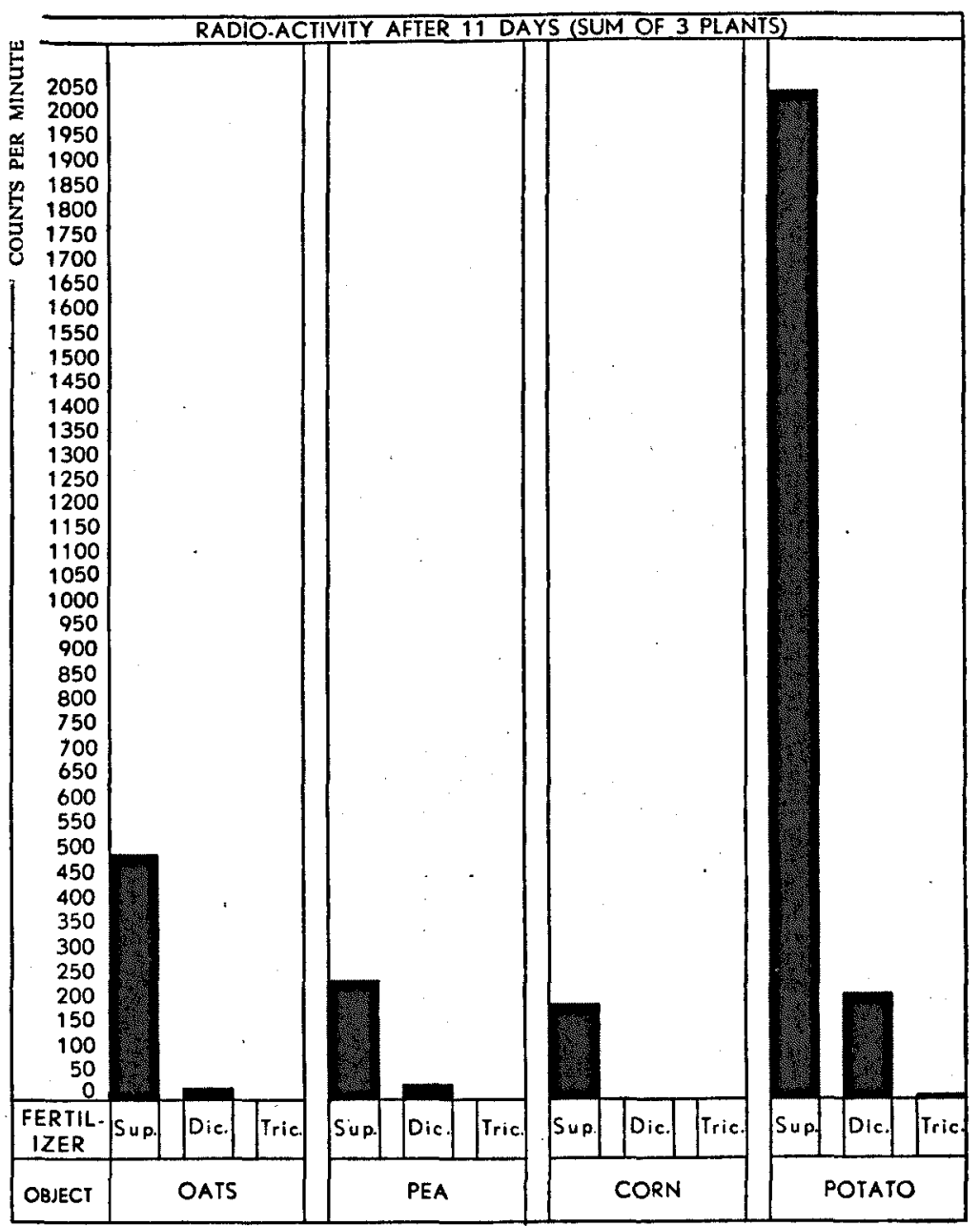

Fig. 5. Measurements of radio-Activity of various crops 11 days after fertitizer APPLICATION.

tions. In this series the $0-1 \mathrm{~cm}$ layer contains less $\mathrm{P}$, in the case of superphosphate than with di-calciumphosphate, whereas the tri-calciumphosphate has remained nearly completely in the top layer. Vertical movement has only occurred with superphosphate and to a lesser degree with di-calciumphosphate.

$\mathrm{P}^{32}$ is, therefore, another aid for proving that water soluble phosphoric acid penetrates more quickly into the soil and consequently may be applied at a later date. If a phosphatic fertilizer is less soluble it should be applied at an earlier date in order to render phosphoric acid available to the roots of the plant.

\section{EXPERIMENTS WITH PLANTS}

Analogous experiments were made with various crops in 12 Mitscherlich pots. The chemical analysis of the soil was as follows : 


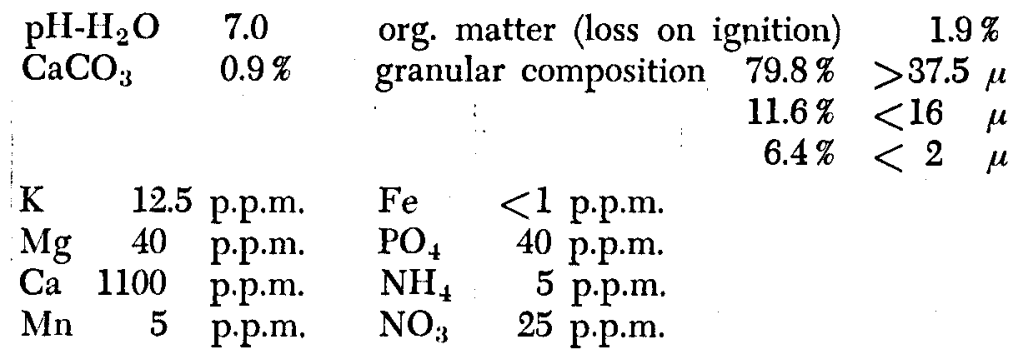

Nitrogen and potash fertilizer was applied on the date of planting or sowing (20-3-1952). The phosphatic fertilizers were applied on 19-4-1952. The dosage of nitrogen and potash varied according to the crop, whereas the quantity of $\mathrm{P}_{2} \mathrm{O}_{\tilde{5}}$ was equal in all cases. See table 3 for details.

Table 3. Scheme of the experiments with Mitscherlich pots.

\begin{tabular}{|c|c|c|c|c|c|}
\hline \multirow{2}{*}{\multicolumn{2}{|c|}{ Crop }} & \multicolumn{3}{|c|}{ Fertilizer $\mathrm{kg} / \mathrm{ha}$} & \multirow{2}{*}{ Form of the phosphatic fertilizer } \\
\hline & & $N$ & $\mathrm{P}_{2} \mathrm{O}_{5}$ & $\mathrm{~K}_{2} \mathrm{O}$ & \\
\hline Oats . & $\cdots \cdots$ & $\begin{array}{l}80 \\
80 \\
80\end{array}$ & $\begin{array}{l}100 \\
100 \\
100\end{array}$ & $\begin{array}{l}130 \\
130 \\
130\end{array}$ & $\begin{array}{l}\text { superphosphate } \\
\text { di-calciumphosphate } \\
\text { tri-calciumphosphate }\end{array}$ \\
\hline Peas & $\cdots$ & $\begin{array}{l}50 \\
50 \\
50\end{array}$ & $\begin{array}{l}100 \\
100 \\
100\end{array}$ & $\begin{array}{l}120 \\
120 \\
120\end{array}$ & $\begin{array}{l}\text { superphosphate } \\
\text { di-calciumphosphate } \\
\text { tri-calciumphosphate }\end{array}$ \\
\hline Maize & $\cdots$ & $\begin{array}{l}80 \\
80 \\
80\end{array}$ & $\begin{array}{l}100 \\
100 \\
100\end{array}$ & $\begin{array}{l}160 \\
160 \\
160\end{array}$ & $\begin{array}{l}\text { superphosphate } \\
\text { di-calciumphosphate } \\
\text { tri-calciumphosphate }\end{array}$ \\
\hline Potato & $\cdots$ & $\begin{array}{l}140 \\
140 \\
140\end{array}$ & $\begin{array}{l}100 \\
100 \\
100\end{array}$ & $\begin{array}{l}200 \\
200 \\
200\end{array}$ & $\begin{array}{l}\text { superphosphate } \\
\text { di-calciumphosphate } \\
\text { tri-calciumphosphate }\end{array}$ \\
\hline
\end{tabular}

The radio-activity of the quantity of phosphate applied to each pot was $300 \mu \mathrm{c}$. Each pot contained 3 oat-, pea- or maize-plants. In the case of potatoes each pot contained one tuber.

When measuring radio-activity of foliage the Geigercounter tube was placed in such a position that the end window was completely covered by the leaf.

Figure 5 shows the results of the measurements made 11 days after fertilizer application. This figure shows that only water soluble $\mathrm{P}_{2} \mathrm{O}_{5}$ is quickly available to the plant when fertilizer is applied late.

Measurements were made at the maize leaves to trace the distribution of the phosphoric acid in the plant. Figure 6 shows that the lower leaves had assimilated less $\mathrm{P}_{2} \mathrm{O}_{5}$ from the fertilizer than the higher leaves.

The relationship between the relative age of the leaf and the quantity of assimilated phosphoric acid becomes still more interesting when the various phosphatic fertilizers are compared. Figures 7 and 8 show this comparison for the foliage of peas and potatoes 20 days after fertilizer application.

We know that important physiological differences may exist between individual plants of any one crop under otherwise equal growing conditions. These differences were also plainly noticeable during these experiments. It was also 


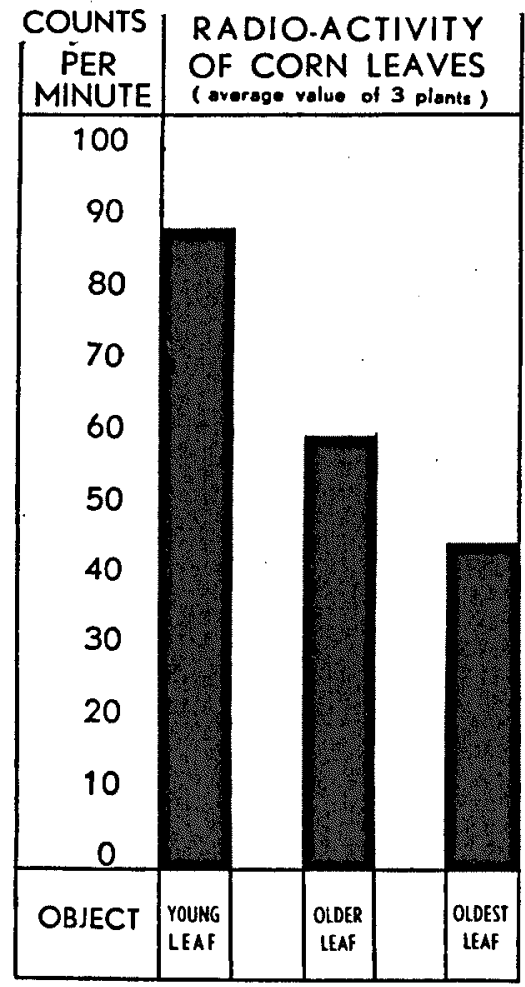

Fig. 6. Quantity of $\mathrm{P}_{2} \mathrm{O}_{5}$ assimilated by Leaves of Diffehent ages.

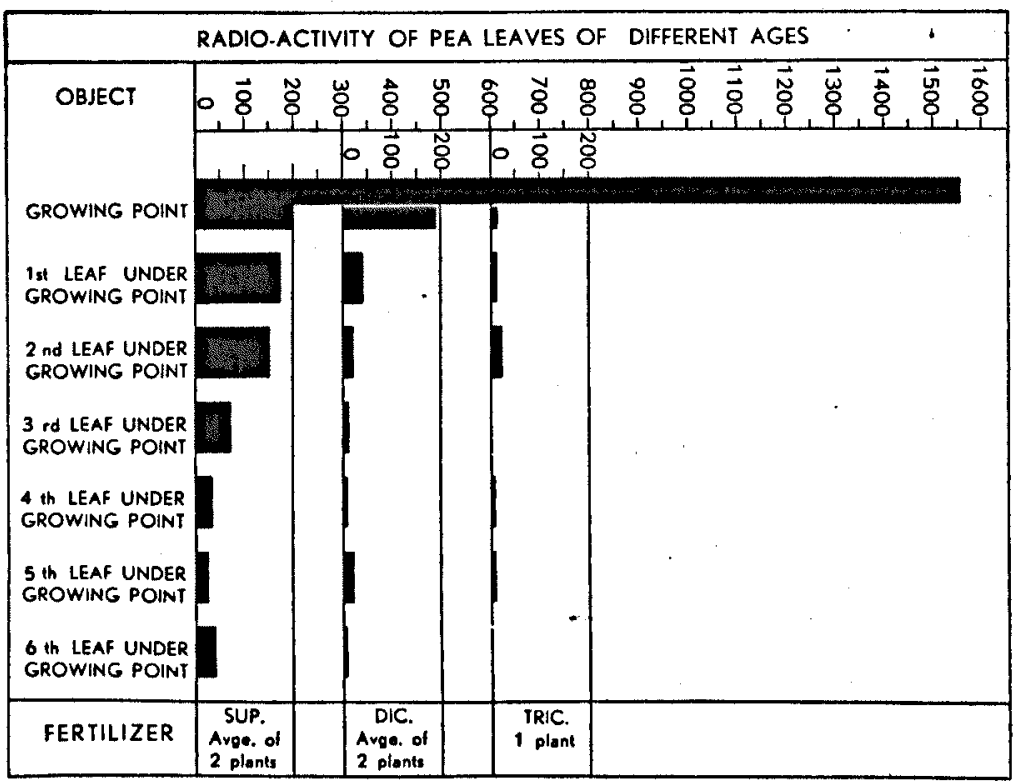

Fig. 7. Rhio-activity of PEa foltage Measured along tile STEM fRom basis to top. 


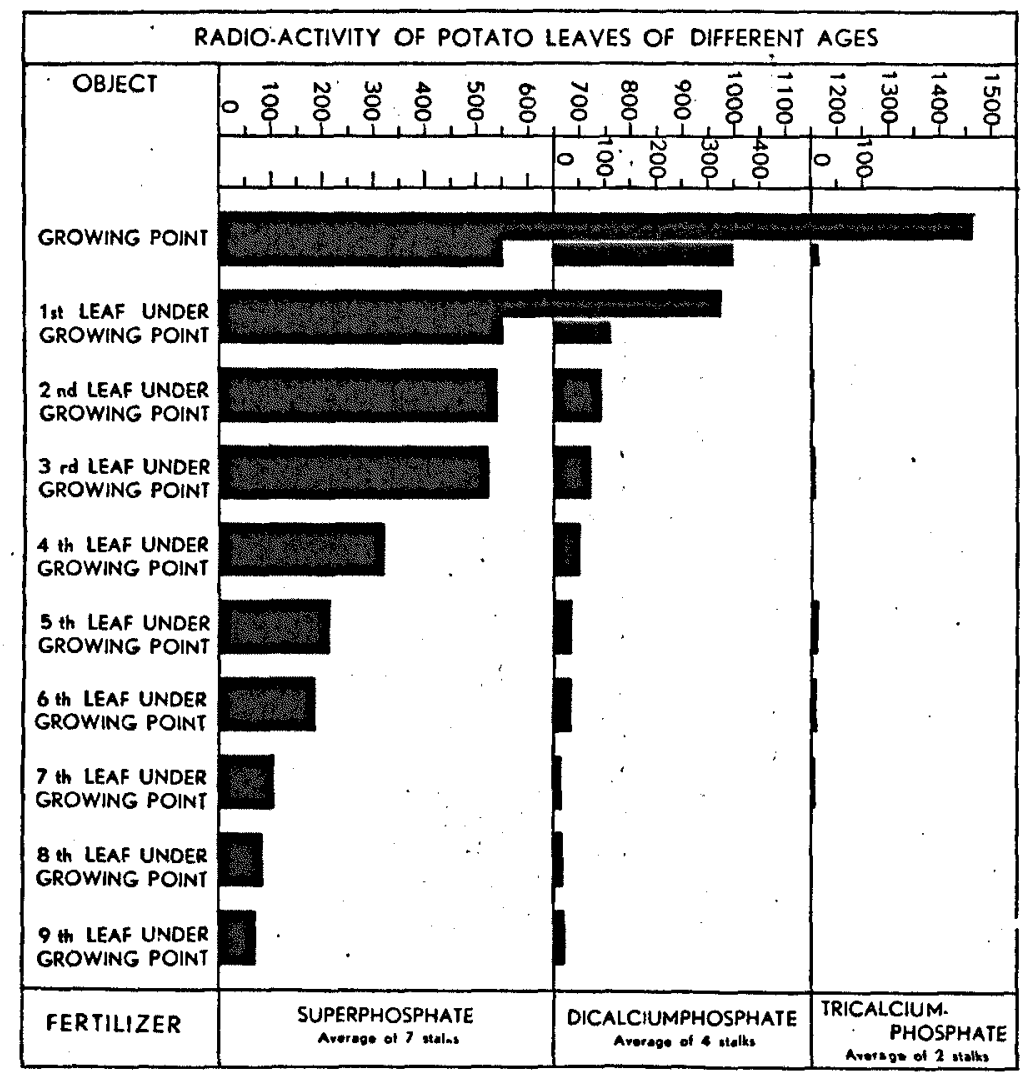

Fig. 8. Content of $P^{32}$ in the foliage of potato plants MEasuned along stem from SOIL UPWARD.

apparent that these differences occurred between the various stems of one single plant. Measurements at the stems of one single potato plant indicated that the leaves on one stem contained three times the quantity of $\mathrm{P}_{2} \mathrm{O}_{5}$ as compared with another stem. Table 4 shows the relevant figures.

Table 4. Measurements of radio-activity of leaves of equal age on different stems of one single potato plant.

\begin{tabular}{c|c}
\hline Stem No. & Counts per minute \\
\hline 1 & 342 \\
2 & 1091 \\
3 & 677 \\
\hline
\end{tabular}

